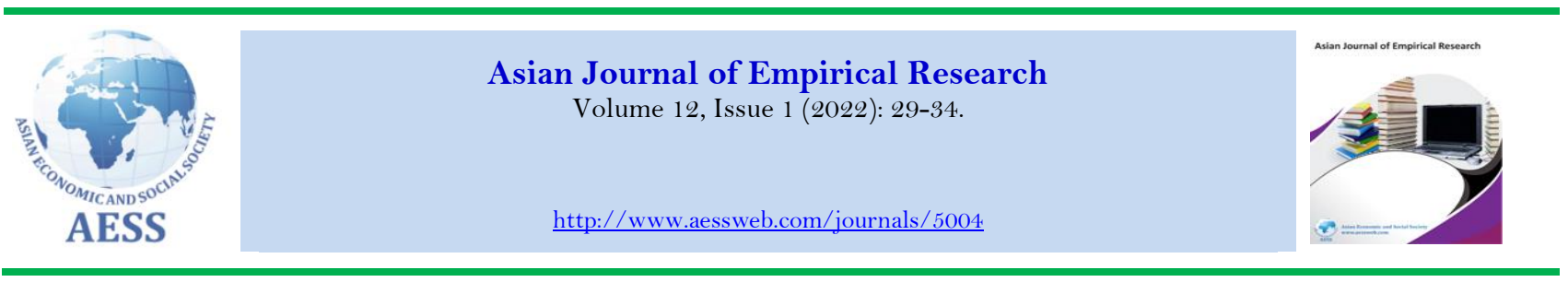

\title{
IMPACT OF BOARD DIVERSITY ON FIRMS' STABILITY: A STUDY ON EUROPEAN FIRMS
}

Farjana Nasrin

\begin{tabular}{l} 
Article History \\
\hline Received: 17 Decer \\
Revised: 21 January \\
Accepted: 4 February \\
Published: 15 Febr \\
Keywords \\
Zscore \\
Firms' stability \\
Board size \\
Diversity on board \\
Board independence \\
European firms'.
\end{tabular}

Department of Business and Technology Management, Islamic University of Technology, Bangladesh.

\section{farjana@iut-dhaka.edu}

Contribution/Originality: This study's primary contribution is to understand the impact of board diversity such as board size, board independence and diversified board member on firms' stability. This study findings suggest that board size with proper number of board members with having diversity lead to enhance firms' value and stability.

DOI: $10.18488 / 5004 . v 12 \mathrm{i} 1.4422$

$\operatorname{ISSN}(\mathrm{P}):$ 2306-983X/ISSN(E): 2224-4425

How to cite: Farjana Nasrin (2022) Impact of Board Diversity on Firms' Stability: A Study on European Firms. Asian Journal of Empirical Research, 12(1), 29-34. 10.18488/5004.v12i1.4422

(C) 2022 Asian Economic and Social Society. All rights reserved.

\section{INTRODUCTION}

Ensuring firms' stability is a major concern of all firms which depends on a number of board issues such as; assets, equity, financial strength, board ownership, board size, composition, board diversity and board independence etc. (Bei \& Wijewardana, 2012; Vu, Phan, \& Le, 2018). Stability of firm refers the ability of maintaining uncertain financial circumstances with proper resource capacity for a long time. Measuring stability with Zscore has been increasing in recent years (Dwumfour, 2017; Emongor, Musau, \& Mwasiaji, 2020) which refers the measure of firms' default risk corresponds to Altman Zscore (Altman, Iwanicz-Drozdowska, Laitinen, \& Suvas, 2017; Ijtsma, Spierdijk, \& Shaffer, 2017; Karkowska \& Acedański, 2020). In this study, winsorised Zscore is used as a measure of firms' stability to understand its impact on board diversity.

The board of directors of a firm are more concerned about ensuring firms' stability though it is quite tough to ensure firms' stability and manage risks all the time with same strength. In this regard, board issues such as board composition, size, diversity, experienced board members, board independence, shareholders' ownership and regular board meetings also have an impact on firms' value and stability (Bernile, Bhagwat, \& Yonker, 2018; Campbell \& Minguez Vera, 2010; Frijns, Dodd, \& Cimerova, 2016; Ruigrok, Peck, \& Keller, 2006).

Based on the above considerations, this study aims to identify the impact of board diversity in terms of size, independence and participation of diversified board members on firms' stability. This empirical study comprises a 6year panel data set from the year 2013 to 2018 of 180 listed firms categorized in 10 economic sectors operating in 22 European countries. Here, wZscore has been used as a proxy measure of firms'stability to understand the influence of 
board size, diversity on board and board independence on it. To identify the relationships, regression models are constructed on a sample of European firms.

The empirical results of this study found that board size has a significant negative influence on firms' stability measured by wZscore. Besides, diversity on board and board independence have significant positive impact on firms' stability. The remaining of this paper is organized as follows: section 2 provides literature review; section 3 describes research methodology; section 4 describes findings and analysis; section 5 describes conclusions and implications of this study.

\section{LITERATURE REVIEW}

\subsection{Board Size and Firms' Stability}

Board size refers the number of board members of a firm including CEO, board of directors, executive and nonexecutive directors. The author Cheng (2008) found that larger board size will produce less variability in corporate board performance in terms of return on assets, stocks. Another study shows that larger board having non-executive board member is more stable financial position in terms of low liquidity risk, credit risk and asset risk etc. (Trinh, Elnahass, Salama, \& Izzeldin, 2020). He added that board members' expertise and experience lead to more stable performance of the firms.

As a result of greater access of numerous areas and networks, larger board size can have a positive impact on firms' performance. Besides, there exists a significant positive impact of board size on firms' stability when a good number of board members are independent (Lassoued, 2018). However, larger board size with a number of outside directors can also be challenging if the board members are loaded with numerous responsibilities and frequent unnecessary board meeting (Jackling \& Johl, 2009).

Also, the authors Karkowska and Acedański (2020); Bonn, Yoshikawa, and Phan (2004) found that there exists a negative impact of board size on firms' stability. The studies of Kao, Hodgkinson, and Jaafar (2019); Chalmers, Hay, and Khlif (2019) also support the findings by examining that small board size can influence on enhancing firm value while large board size might cause inefficiency. Based on the above literature support, the following hypothesis can be developed.

H1: Board size has a negative impact on firms' stability.

\subsection{Diversity of Board Members and Firms' Stability}

Board diversity refers having diversified board member in board composition in terms of gender, race, ethnicity and age etc. which will create impact on stability of the firms. Board diversity impacts on firms' performance as well as firms' stability whether positive, negative or mixed. Due to having differences in culture, communication pattern and perception among the board members, national diversity in board members have negative impacts on firms' performance and stability (Khan \& Abdul Subhan, 2019).

The study of Vu et al. (2018) found that there is no such significant influence of women board members on firms' performance as well as stability. Having women on board and board members' ethnicity have significant negative impact on firms' financial stability as of having inefficiency in maintaining resource and agency issues by protecting the financial distress of a company (Al-Absy, Almaamari, Alkadash, \& Habtoor, 2020). Also, more women onboard are more challenging to ensure sustainable stability and profitability of banks (Hoang, 2021).

However, female participation on board positively impacts on firms' value creation and stability (Khan \& Abdul Subhan, 2019). Hoang (2021) stated that having female board member specially banks with female CEO creates a positive impact on firms' stability.

According to Karkowska and Acedański (2020) board diversity can affect positively on firms' long-term stability by taking proper decisions with diversified opinion of board members. Ooi, Hooy, and Som (2015) added that in financial crisis period the effects of board diversity are moderated. More diversity on board will create more persistent policies which will lead to less volatility and better performance of firms (Bernile et al., 2018). Diversity on board has a positive effect on firms' stable position by enforcing better managerial decisions (Bonn et al., 2004). Based on above literature support and studies, we can conclude the following hypothesis regarding board diversity and firms' stability.

H2: Diversity of board members has a positive impact on firms' stability.

\subsection{Board Independence and Firms' Stability}

Board independence refers to have independent board members in board of directors to take board decisions with proper independence. There exists debate on whether board independence will positively impact on stability of firms with managing conflict of interests of the stakeholders (Fernandes, 2008). Moreover, there is no such conclusive linkage between board independence and firms' value according to theoretical and empirical findings (Luan \& Tang, 2007). Also, board independence from agency-cost perspective is less efficient in terms of ensuring stability (McCahery \& Vermeulen, 2014).

Sometimes independent board may be not so efficient rather than constrains the stability with increasing risks (Karkowska \& Acedański, 2020). The study of Vu et al. (2018) found that there is no such significant influence of independent board members on firms' performance as well as stability. Besides, more independent members who are dominated by the firm-related directors are unable to perform their tasks independently found in the study of Palmberg (2015). Another interesting issue found in the study of Masulis and Mobbs (2014) states that, independent board members work better when firms' overall performance and stability gets better. 
However, more independent members on board will create more value having positive impact on stability of the firms (Chen \& Zhou, 2007; Chen, Lin, Lin, \& Hsiao, 2016). Increase of board independence can enhance firms' value when the independent board members can work independently without the influence of management body or social ties (Hoitash, 2011). Board independence positively influence on firms' financial performance through which a firm can ensure stable situation (Palmberg, 2015). Based on the above discussion, it can be concluded that board independence of a firm positively influence the firms' stability. Hence, the following hypothesis can be developed.

H3: Board independence has a positive impact on firms' stability.

\section{RESEARCH METHODOLOGY}

\subsection{Sample Selection and Data Source}

The purpose of this study is to analyze the impact of board diversity (board size, board diversity, independent board, experienced board) on Zscore as a measure of firms' stability. Our study comprises a 6-year panel data set from the year 2013 to 2018 of 180 listed firms categorized in 10 economic sectors operating in 22 countries. Thomson Reuters database has been used as the source of information. Global Gender Gap index and World Governance Indicator from World Economic Forum and World Bank are the other sources of data. The Global Gender Gap Index introduced by the World Economic Forum is a framework for capturing the magnitude of gender-based disparities and tracking their progress over time. And theWorldwide Governance Indicators (WGI) reports aggregate and individual governance indicators for over 200 countries and territories over the period 1996-2021, for six dimensions of governance including voice and accountability, political stability, governance effectiveness etc.

In the empirical analysis of this study, some irrelevant information have been removed to minimize the biasness of results such as observations of non-European countries, if the country headquarter is in Bermuda, Mexico, Singapore, United states, Russia, Faroe-island and if the GICS Sector Code is 40.

\subsection{Variables Measurement}

In this empirical study, Zscore has been used as dependent variable which measures firm's stability.A 6-year panel data set has been used here to test the hypothesis of regression model. Firm's stability refers the ability of a firm to cope up with unpredictable situation without much deviation of firms' assets and equity. Here, winsorised Zscore (wZscore) is used as a proxy measure of firms' stability which refers afirm's default risk corresponds to Altman Zscore (Agarwal \& Taffler, 2008; Al Zaabi, 2011).

To identify whether board diversity can have influences on firm's stability, several independent variables as proxy of board diversity have been used in this study such as: board size, board diversity and board independence.

Board diversity refers the board characteristics including board size which refers board composition and total number of directors on board (Beiner, Drobetz, Schmid, \& Zimmermann, 2004). Another variable such asboard diversity refers having male and female directors and different ethnic group members on board (Carter, Simkins, \& Simpson, 2003); diversity in terms of age of the board members (Ferrero-Ferrero, Fernández-Izquierdo, \& MuñozTorres, 2015).Here in this study, policy board diversity is used the proxy variable of board diversity. Another proxy variable of board diversity is board independence which refers independent board withnon-executive board members totake proper decision independently (Palmberg, 2015).

In this empirical study, to minimize model misinterpretation several control variables have been used such as: ownership (shareholders' ownership of firm), board meeting attendance and experienced board to run the regression model. Random effect and fixed effect regression model have been constructed in this study where these control variables are used to understand the influence on Zscore as a measure of firm's stability.

\subsection{Methodology}

This study is based on panel data estimation with econometric model. There are several unobserved heterogeneity problems as limitation (Gormley \& Matsa, 2014) which measures the time-invariant variables of firms. Besides, there might be endogeneity problem arises as of causality relationship between several independent variables stated in the work of Wintoki, Linck, and Netter (2012).

In this study winsorized Zscore (wZscore) has been used as a proxy variable of firms' stability which corresponds to Altman Zscore (Altman et al., 2017). It increases as default risk decreases of a firm. Besides, to get a better understanding about the impact of independent variables on firms' stability, wZscore has been multiplied by negative 1 (denoted as negwZscore) in this study. Regression model has been run to understand the influence of these variables on firm's stability with normalizing the distribution of all the variables of this model.In this study, we have used fixed effect model and rejected the absence of firm specific impact as a preliminary estimate, which suggests that ordinary least squared (OLS) calculations are inconsistent, and FE and RE estimations are more appropriate where STATA command xtreg fits panel-data linear models. Model:

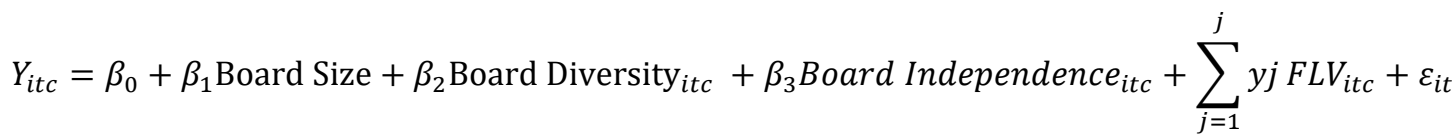

Here, Y represents alternative measures of negwZscoreas dependent variable which measures firms' stability. Board Size, Board Diversity, and Board Independence re the three independent variables. FLV refers the firm level control variables $\mathrm{J}=3$, corresponding toshareholders' ownership, average board meeting attendance and experienced board. And cit is the stochastic error term. 


\section{RESULTS AND ANALYSIS}

\subsection{Multivariate Analysis}

The following Table 1 shows the empirical findings that are used to test the hypothesis to understand the impact of board diversity on zscore as a measure of firm's stability. Here, winsorized Zscore (wZscore) has been used for which multiplying wZscore by negative 1 (denoted as negwZscore) provides better relationship among the variables. Table 1 represents the relationship between independent and dependent variables. Here in this study, independent variables have been used such as: board size, board diversity and board independence. This table also shows several control variables such as: ownership (shareholders' ownership of firm), board meeting attendance and experienced board.

Table 1. Multivariate analysis.

\begin{tabular}{l|c|c}
\hline Variables & $(\mathbf{1})(\mathbf{f e})$ & $(\mathbf{2})(\mathbf{r e})$ \\
\hline & $-13.69^{* *}$ & $-13.69^{* *}$ \\
Own 1 & $(6.850)$ & $(6.850)$ \\
\hline & $-0.710^{* * *}$ & $-0.710^{* * *}$ \\
Board Size & $(0.132)$ & $(0.132)$ \\
\hline & $2.721^{* * *}$ & $2.721^{* * *}$ \\
Policy Board Diversity & $(0.550)$ & $(0.550)$ \\
\hline & 0.00460 & 0.00460 \\
Board Meeting Attendance Avg_w & $(0.0611)$ & $(0.0611)$ \\
\hline & $0.0738^{* * *}$ & $0.0738^{* * *}$ \\
Analytic Indep Board & $(0.0223)$ & $(0.0223)$ \\
\hline & $0.430^{* *}$ & $\left(0.430^{* *}\right.$ \\
Analytic Experienced Board & $(0.179)$ & $22.35^{* * *}$ \\
\hline & $22.35^{* * *}$ & $(6.918)$ \\
Constant & $(6.918)$ & 89 \\
\hline Observations & 89 & 0.520 \\
\hline R-squared & 0.520 & 15 \\
\hline Number of Iden & 15 &
\end{tabular}

According to Hypothesis 1, Board size has a negative impact on firms' stability. The relationships are also statistically significant under both fixed and random effect model. The study result states that larger board size may create work inefficiency and less positive output as a result of miscommunication and coordination problem. Besides, there might be a chance of arising greater agency problem when a number of board members exist on board.

According to hypothesis 2, board diversity has a positive influence on firms' stability which also reflects significant relationship in the empirical result. The findings of this empirical study show that firms' stability increases with a diversified board with enforcing better managerial decision. Female participation on board also impacts on creating more value of firms as of more persistent policies with diversified perceptual thinking. Besides, board diversity leads to better performance of firms as of having fewer volatile outcomes in decision making.

According to hypothesis 3, board independence has positive influence on firms' stability. The study result also states significant positive relationship between board independence and firms' stability. When the board members can perform their duties independently without the influences of management body or social ties, it will create more positive outcome on firms' stability.

Finally, this empirical study recommends that firms' stability depends on a number of issues such as board size, diversity on board, board independence, firms' ownership, board meeting attendance, experienced board and so on. Proper policy implementation of proper board size, ensuring the positive outcome of diversity, asset investment, board independence management, shareholders' ownershipcan make a more sustainable stability of firms.

\section{CONCLUSIONS AND IMPLICATIONS}

This study examines the impact of board issues such as board size, diversity on board and board independence on firms' stability measured by wZscore through and empirical approach. Based on previous studies, board size, diversity and independence can have significant impacts on stability of the firms. In this study, a sample of 180 listed economic sector of the European Union for which a 6-year panel data set from the year 2013 to 2018 has been constructed.

This study finds that firm's stability measured by wZscore further constructed with negative 1 to have better understanding, is statistically significant with board size, diversity and independence. Board size is statistically significant and negatively influence on firms' stability which means when firm has a large number of board members, it will create inefficiency in decision making. Rather larger board may cause complexity in coordination and communication issues with agency problem. So, to get a more stability of firms, proper number of board members will enhance the value of a firm.

Besides, this study also found that diversity on board (such as: gender, race, ethnic and cultural diversity) has a significant influence on firms' stability measured by zscore. In this empirical study, diversity on board positively influence on firms' stability. Also, female participation on board will enhance more persistent and less volatility in managerial decision making which will lead to longer stability of firms'. 
Another result of this study also states that board independence has a significant positive impact on zscore as a measure of firms' stability. That means, when a firm can work and take decisions independently without pressure from other influential bodies, firms' stability increases as a result of better work performance and proper policy implementation. As a result, firm can cope up with unprecedented business circumstances with maintaining its equity and assets.

However, this empirical study didn't cover the estimates of non-European firms, emerging economies and other countries. Besides, significance of all other variables which may have influences on firms' stability are not explained here. Also, a larger number of sample of other countries might add some valuable implications over this findings. Data availability remains an issue in this study as well.

Funding: This study received no specific financial support.

Competing Interests: The author declares that there are no conflicts of interests regarding the publication of this paper.

Views and opinions expressed in this study are the authors' views and opinions; the Asian Journal of Empirical Research shall not be responsible or answerable for any loss, damage, or liability, etc. caused in relation to/arising out of the use of the content.

\section{REFERENCES}

Agarwal, V., \& Taffler, R. (2008). Comparing the performance of market-based and accounting-based bankruptcy prediction models. Journal of Banking \& Finance, 32(8), 1541-1551.Available at: https://doi.org/10.1016/j.jbankfin.2007.07.014.

Al-Absy, M. S. M., Almaamari, Q., Alkadash, T., \& Habtoor, A. (2020). Gender diversity and financial stability: Evidence from malaysian listed firms. The Journal of Asian Finance, Economics, and Business, 7(12), 181-193.Available at: https://doi.org/10.13106/jafeb.2020.vol7.no12.181.

Al Zaabi, O. S. H. (2011). Potential for the application of emerging market Z-score in UAE Islamic banks. International Journal of Islamic and Middle Eastern Finance and Management, 4(2), 158-173.Available at: https://doi.org/10.1108/17538391111144498.

Altman, E. I., Iwanicz-Drozdowska, M., Laitinen, E. K., \& Suvas, A. (2017). Financial distress prediction in an international context: A review and empirical analysis of Altman's Z-score model. Journal of International Financial Management E Accounting, 28(2), 131-171.Available at: https://doi.org/10.1111/jifm.12053.

Bei, Z., \& Wijewardana, W. (2012). Financial leverage, firm growth and financial strength in the listed companies in Sri Lanka. Procedia-Social and Behavioral Sciences, 40, 709-715.Available at: https://doi.org/10.1016/j.sbspro.2012.03.253.

Beiner, S., Drobetz, W., Schmid, F., \& Zimmermann, H. (2004). Is board size an independent corporate governance mechanism? Kyklos, 57(3), 327-356.Available at: https://doi.org/10.1111/j.0023-5962.2004.00257.x.

Bernile, G., Bhagwat, V., \& Yonker, S. (2018). Board diversity, firm risk, and corporate policies. Journal of Financial Economics, 127(3), 588-612.Available at: https://doi.org/10.1016/j.jfineco.2017.12.009.

Bonn, I., Yoshikawa, T., \& Phan, P. H. (2004). Effects of board structure on firm performance: A comparison between Japan and Australia. Asian Business \& Management, 3(1), 105-125.Available at: https://doi.org/10.1057/palgrave.abm.9200068.

Campbell, K., \& Minguez Vera, A. (2010). Female board appointments and firm valuation: Short and long-term effects. Journal of Management \& Governance, 14(1), 37-59.

Carter, D. A., Simkins, B. J., \& Simpson, W. G. (2003). Corporate governance, board diversity, and firm value. Financial Review, 38(1), 33-53.

Chalmers, K., Hay, D., \& Khlif, H. (2019). Internal control in accounting research: A review. Journal of Accounting Literature, 42, 80103.Available at: https://doi.org/10.1016/j.acclit.2018.03.002.

Chen, K. Y., \& Zhou, J. (2007). Audit committee, board characteristics, and auditor switch decisions by Andersen's clients. Contemporary Accounting Research, 24(4), 1085-1117.

Chen, C.-J., Lin, B.-W., Lin, Y.-H., \& Hsiao, Y.-C. (2016). Ownership structure, independent board members and innovation performance: A contingency perspective. Journal of Business Research, 69(9), 3371-3379.Available at: https://doi.org/10.1016/j.jbusres.2016.02.007.

Cheng, S. (2008). Board size and the variability of corporate performance. Journal of Financial Economics, 87(1), 157-176.Available at: https://doi.org/10.1016/j.jfineco.2006.10.006.

Dwumfour, R. A. (2017). Explaining banking stability in Sub-Saharan Africa. Research in International Business and Finance, 41, 260279.Available at: https://doi.org/10.1016/j.ribaf.2017.04.027.

Emongor, E., Musau, S., \& Mwasiaji, E. (2020). Non-interest income and insolvency risk of commercial banks in Kenya. Journal of Finance and Accounting, 4(5), 41-54.Available at: https://doi.org/10.1016/j.ribaf.2017.04.027.

Fernandes, N. (2008). EC: Board compensation and firm performance: The role of "independent" board members. Journal of Multinational Financial Management, 18(1), 30-44.Available at: https://doi.org/10.1016/j.mulfin.2007.02.003.

Ferrero-Ferrero, I., Fernández-Izquierdo, M. Á., \& Muñoz-Torres, M. J. (2015). Integrating sustainability into corporate governance: An empirical study on board diversity. Corporate Social Responsibility and Environmental Management, 22(4), 193-207.Available at: https://doi.org/10.1002/csr.1333.

Frijns, B., Dodd, O., \& Cimerova, H. (2016). The impact of cultural diversity in corporate boards on firm performance. Journal of Corporate Finance, 41, 521-541.Available at: https://doi.org/10.1016/j.jcorpfin.2016.07.014.

Gormley, T. A., \& Matsa, D. A. (2014). Common errors: How to (and not to) control for unobserved heterogeneity. The Review of Financial Studies, 27(2), 617-661.Available at: https://doi.org/10.1093/rfs/hhto47.

Hoang, Y. (2021). Do female leaders influence bank profitability and bank stability?: Evidence from Vietnamese banking sector. Economics and Business Letters, 1O(3), 262-273.Available at: https://doi.org/10.17811/ebl.10.3.2021.262-273.

Hoitash, U. (2011). Should independent board members with social ties to management disqualify themselves from serving on the board? Journal of Business Ethics, 99(3), 399-423.Available at: https://doi.org/10.1007/s 10551-010-0660-5. 
Ijtsma, P., Spierdijk, L., \& Shaffer, S. (2017). The concentration-stability controversy in banking: New evidence from the EU-25. Journal of Financial Stability, 33(C), 273-284.

Jackling, B., \& Johl, S. (2009). Board structure and firm performance: Evidence from India's top companies. Corporate Governance: An International Review, 17(4), 492-509.

Kao, M. F., Hodgkinson, L., \& Jaafar, A. (2019). Ownership structure, board of directors and firm performance: evidence from Taiwan. Corporate Governance: The International Journal of Business in Society, 19(1), 189-216.

Karkowska, R., \& Acedański, J. (2020). The effect of corporate board attributes on bank stability. Portuguese Economic Journal, 19(2), 99-137.

Khan, A. W., \& Abdul Subhan, Q. (2019). Impact of board diversity and audit on firm performance. Cogent Business छ Management, 6(1), 1611719.Available at: https://doi.org/10.1080/23311975.2019.1611719.

Lassoued, M. (2018). Corporate governance and financial stability in Islamic banking. Managerial Finance, 44(5), 524-539.

Luan, C. J., \& Tang, M. J. (2007). Where is independent director efficacy? Corporate Governance: An International Review, 15(4), 636643.Available at: https://doi.org/10.1111/j.1467-8683.2007.00593.x.

Masulis, R. W., \& Mobbs, S. (2014). Independent director incentives: Where do talented directors spend their limited time and energy? Journal of Financial Economics, 11 1(2), 406-429.Available at: https://doi.org/10.1016/j.jfineco.2013.10.011.

McCahery, J. A., \& Vermeulen, E. P. (2014). Understanding the board of directors after the financial crisis: Some lessons for Europe. Journal of Law and Society, 41(1), 121-151.Available at: https://doi.org/10.1111/j.1467-6478.2014.00659.x.

Ooi, C.-A., Hooy, C.-W., \& Som, A. P. M. (2015). Diversity in human and social capital: Empirical evidence from Asian tourism firms in corporate board composition. Tourism Management, 48, 139-153.Available at: https://doi.org/10.1016/j.tourman.2014.11.002.

Palmberg, J. (2015). The performance effect of corporate board of directors. European Journal of Law and Economics, 40(2), $273-292$.

Ruigrok, W., Peck, S. I., \& Keller, H. (2006). Board characteristics and involvement in strategic decision making: Evidence from Swiss companies. Journal of Management Studies, 43(5), 1201-1226.Available at: https://doi.org/10.1111/j.14676486.2006.00634.x.

Trinh, V. Q., Elnahass, M., Salama, A., \& Izzeldin, M. (2020). Board busyness, performance and financial stability: Does bank type matter? The European Journal of Finance, 26(7-8), 774-801.Available at https://doi.org/10.1080/1351847x.2019.1636842.

Vu, M.-C., Phan, T. T., \& Le, N. T. (2018). Relationship between board ownership structure and firm financial performance in transitional economy: The case of Vietnam. Research in International Business and Finance, 45, 512-528.Available at: https://doi.org/10.1016/j.ribaf.2017.09.002.

Wintoki, M. B., Linck, J. S., \& Netter, J. M. (2012). Endogeneity and the dynamics of internal corporate governance. Journal of Financial Economics, 105(3), 581-606.Available at: https://doi.org/10.1016/j.jfineco.2012.03.005. 